\section{State Failure in India: \\ Political-Fiscal Implications of the Black Economy}

Rathin Roy

IDS Bulletin Vol 27 No 21996

\section{Introduction $^{1}$}

The most popular paradigm currently explaining state failure in India falls within the broad church of neo-liberal political economy (NPE). This paradigm's popularity in recent work on India extends to official and academic circles. The picture of the Indian state that emerges in the NPE paradigm is a generalized one: a predatory state, debilitating society by generating rent-seeking impulses. In previous work we sought to evaluate the fulminations of this school, by looking at whether the NPE picture of Indian state failure was validated by the fiscal record of the Indian state. We found it difficult to see a vindication of the NPE hypothesis in government expenditure data on India; indeed it was possible to reject this plank of the NPE hypothesis using an analysis of the government fiscal record from 1960 to 1985 (Roy 1994; 1995).

An important part of the NPE analysis is 'rent-seeking'. Here, it emerged there is a considerable consensus even among those who dissent from the NPE view that 'rent-seeking' was, if not a cause, then at least a symptom of Indian state failure. There is evidently a rare consensus that Indian economic atrophy could be linked to the fact that the rent-seeking Indian state did not (Rudolph and Rudolph 1987), could not (Lal 1988), or would not (Bardhan 1984) provide an adequate basis for state-led development. ${ }^{2}$ We feel that this superficial unity in diagnosis is, possibly, generated by the portmanteau way in which the term 'rent-seeking' is used.

Explaining this consensus requires a theoretical and empirical unpacking of the notion of rentseeking and its application to Indian political and fiscal realities. Clearly, corruption has been a central notion that, prima facie, unifies various strands of thought about rent-seeking. This article presents some of that unpacking with particular attention to the emergence of the 'black economy' in India and the role of corruption in that emergence. We argue that the black economy played a critical role in the softening of the government budget constraint in the 1980s, inter alia, it reflects a

\footnotetext{
${ }^{1}$ I would like to thank Barbara Harriss-White for her comments on an earlier draft of this paper.

A detailed discussion of these positions can be found in Roy (1994).
} 
decline in the fiscal surplus accessible to the state. The origins and disposition of black income are traceable, it is argued, to petty bourgeois groups rather than to direct corruption of the type identified in the rent-seeking literature.

\section{Rent-Seeking, the 'Black Economy' and Corruption}

The theory of rent-seeking argues that state intervention incurs losses when resources are unproductively diverted in order to capture rents generated by state intervention. ${ }^{3}$ Rents are unproductive when they are spent in resource re-allocation rather than resource creation (Buchanan 1980). Attempting to eliminate rent-seeking without changing the conditions in which rents are generated, merely changes the locus of rents. Significantly, state restrictions on private activity (such as licensing) generate credentials - rights to engage in activity that is restricted by the state - the possession of which gives the credential holder access to rents. Activity then focuses on the acquisition (by private agents) and disbursement (by the state) of these credentials, leading over time to a situation where the activity negatively affects people's perception of the legitimacy of the economy system (Krueger 1974; Chang 1994).

Whatever the merits of the core idea underlying rent-seeking the concept can be, and is, widely interpreted. In our context two points need mentioning: i) it is unclear whether rent-seeking is bad because it generates high transaction-costs or whether it is the transfer element which is a problem; and ii) it is possible to find societies which survive with high levels of rent-seeking and yet achieve both political stability and economic growth (Khan 1989; Chang 1994). Confusion lies in the fact that there are two judgements involved here: whether it is the costs generated by rent-seeking that undermine state capacity, or whether it is the rights that generate rents that undermine state capacity. To elucidate this issue, we need to introduce some theoretical clarifications which trace the links between rent-seeking, corruption and clientelism.
State intervention has been identified by sociologists as an arena of patron-client transactions. The seminal work on this subject in the context of South Asia is that of Khan (1989). Khan argues the importance of one particular form of patron-client exchanges - 'clientelism' - which provides an explanation alternative to that of rent-seeking for differences in the efficiency of states over time and between countries. In his article in this Bulletin, Khan explicates the linkages between clientelism, corruption and rent-seeking, on which the following argument is heavily based.

\section{Clientelism, Rights and Fiscal Policy: Some Political-Fiscal Accounting}

We begin by defining the fiscal surplus as the sum of income flows and wealth stocks to which the state has access through its tax and borrowing instruments given the institutional arrangements in a particular society. What are the elements of fiscal surplus? Institutional arrangements, in the above definition, pertain to the structure of rights extant in a given society plus the political settlement that legitimates these rights. ${ }^{4}$ Typically, the rights generating government revenues are the rights to tax, to borrow, to run a deficit and, in the context of an open economy to bargain internationally to secure credit and aid. In a mixed economy, we can add to this the state's ability to impose restrictions on the activities of other agents. Thus the state's ability to impose restrictions on the activity of potentially competitive agents can earn it revenues from productive activity and from direct investment of the resources it accumulates.

The rights generating government expenditures are more complex. Clearly, the very nature and scope of the political settlement itself generates state expenditures. The precise magnitudes and pattern of state expenditure are dependent on the concrete historical nature of the political settlement. In general, the fact that the state is vested with coercive power generates security expenditure. Further, some expenditures flow from the very rights that

\footnotetext{
${ }^{3}$ Rents are defined as '...that part of the payment to an owner of resources over and above that which those resources could command in any alternative use' (Buchanan 1980: 3).
}

4 For a definition of 'political séttlement', see Khan (1996). 
generate revenues. In industrial democracies, the existence of a welfare state generates an ensemble of taxes and transfers, involving rights which generate revenues as well as expenditures. In command economies and in many mixed economies, the rights to impose restrictions upon the activity of agents generates expenditures for the state in terms of contingent productive activities that the state itself must undertake. In India, for example, the right to exclude private ownership of banks directly obliges the state to provide banking services. Thus, while 'general services' derive fairly unambiguously from the minimal functions of the state, 'social' and 'economic' services involve a more complex set of expenditures.

Where institutional arrangements do not constrain the incidence of the government's fiscal rights, the entire resources of the economy would be the basis for fiscal incidence and there would then be a one-to-one relationship between the size of the GDP, the growth rate and the fiscal surplus. However, wherever institutional arrangements are imperfect and rights are weakly defined, there arises a disjuncture between fiscal incidence in terms of the way in which it is measured in mainstream economics and institutionally constrained fiscal incidence.

The disposable fiscal surplus is the surplus that the state can actually dispose of after the pre-emptive claims to it, including stability payments (defined below) have been made. How the state allocates the disposable fiscal surplus would depend, in the simplest analysis, on the decision makers' perception of how the net present value of social output can be maximized given the political arrangements in place. It differs from the fiscal surplus to the extent that revenue, debt and public expenditure are affected by the need to maintain the political settlement. It is the disposable fiscal surplus that is of central importance to the developmental state, since it is the difference between the fiscal surplus and the disposable fiscal surplus that affects the capacity of the developmental state to articulate a development strategy.

Stability payments occur in situations where stability is a continuous political issue because the rights to certain key assets are continuously contested. Stability payments have two components. When the contest centres around well-defined rights, then the process of contestation can be viewed as a constraint on the maximization of net present value of social product. Rent-seeking is a term that seeks to describe these contingent payoffs. The payoffs which we shall describe as 'clientelist payoffs' - in line with Khan's definition of clientelism - accrue not through some constrained maximization of net present social product but because clientelist lobbies present an immediate threat to disrupt the ability of those in charge of the state to discharge their functions.

This is an important difference. The rent-seeking literature does not distinguish between societies on the basis of the stability of the political settlement. Hence, in that framework, clientelism and rentseeking cannot be distinguished. The stability of the political settlement matters because, while clientelist payoffs are the outcome of weakly defined rights of existing right holders and a distribution of organizational rights that allows payoffs to be gainfully bargained by clientelist organizers, rents are by contrast the outcome of well defined state-imposed restrictions on the market. Rents are generated by scarcity and by the restricted legality of certain types of economic activity where some right holders obtain economic power and credentials which entitle them to capture the difference between scarcity and free-market prices. This difference is generated by the fact that the ability to supply a particular commodity is restricted by credentials (licenses, membership of clubs, parties, lobbies, but also caste and gender, etc.). Clientelist payoffs, conversely, do not originate from the restrictions of supply as a consequence of rights over credentials but, rather, from the ability of a coalition to generate an increase in its resource flow by exerting pressure against existing right-holders. Clientelist surplus appropriation is thus based on the direct bargaining of clientelist lobbies with existing right-holders rather than through restricting the supply of specific goods in the market through protecting rights over credentials. Thus, a growth in the number of rent-extracting credential holders for a particular commodity would 'squeeze' rents, unless market demand for these restricted items grew rapidly enough. However, an increase in the size of a clientelist coalition, would normally increase the amount of resources captured by that coalition (or total clientelist appropriation) because 
the growth in its political power would increase the demand for its services.

In a dynamic context, the revenue and spending aspects of the fiscal surplus can be closely related. Clientelism clearly has a negative effect on the fiscal surplus. An increase in clientelist power can result in a growth in the magnitude of resources outside the reach of the resource mobilization mechanism and represent a potentially major source of variance between the aggregate fiscal surplus and the disposable fiscal surplus. The 'political fiscal statement' (for want of a better phrase) of government activity indicates at a highly simplified level the separate effects of clientelism and rent-seeking on fiscal policy (Figure 1). In it, revenue and expenditure by government is related to the domain of particular rights. This is not yet the beginning of a theory, but merely an attempt to illustrate how such a framework can facilitate a better understanding of the politics of fiscal policy.

In Figure 1, rent-seeking is in one-to-one correspondence with rights, as a result of which this type of activity can potentially generate both revenue and expenditure flows. The ability of the state to meet clientelist payoffs, however, arises as a consequence of rights being weakly defined. For this reason clientelism is not a phenomenon which can be traced to the existence of a specific set of rights since, unlike rent-seeking, it generates no receipts and is an unambiguous drain on the disposable fiscal surplus.

In Figure 1, the disposable fiscal surplus would constitute the excess of the left side over the lower half of the right side. This differentiation is made on the basis of the difference between the rights (and the bargaining over them) that generate stability payments, and other rights. With weakly defined rights, the payoffs in the lower right half of the statement would cause the conventionally measured revenues in the top left half of the statement to be lower than expected. Conventional public expenditure analysis of transfers and subsidies, which ignore rights, cannot distinguish between transfers and subsidies, as we have done, in terms of their sources in the structure and definitiveness of rights that generate them. Further, even approaches (such as the New Institutional Economics) which do discuss alternative allocations of rights without addressing the question of how well rights are defined or whether they are present or absent, would be unable to distinguish between rent-seeking and clientelist payoffs.

\section{Indian Fiscal Policy, the Black Economy and Corruption}

The 'black economy' in this article refers to all activities, legal and illegal which are hidden from the fiscal authorities. This definition is primarily a fiscal definition, the source of concern being not the legality or legitimacy of the economy activity in question, but the fiscal implications of such activity. As such, it is an appropriate definition if the concern is, as here, with identifying the scope of activities that can and do detract from the disposable fiscal surplus.

\subsection{Where do corruption and rent-seeking fit into the black economy?}

Corruption can be defined in a number of ways This is because what is, or is not, an illegal activity is defined by prohibitive laws which vary over time and space. It is too simple to see corruption as merely activities that infringe the law for monetary gain. Corruption is a legal-political construct in that its magnitude and consequences are dependent on the political settlement. The pervasiveness of corruption is a problem when and if the political settlement requires the maintenance and enforcement of rights. In the context of the political-economy, the maintenance of well defined property rights is inhibited by corruption. Here, the magnitude of corruption is important in its impact on the political settlement and on rights. Corruption is a fundamental attack on the stability of the politicoeconomic system. Popular literature on the 'evils' of corruption focus more on this problem. ${ }^{6}$

However, this is not the problem caused by corruption in the rent-seeking literature. In that literature corruption reflects a particular distribution of rents,

\footnotetext{
${ }^{3}$ This distinction is elaborated in Khan (1989).
} 


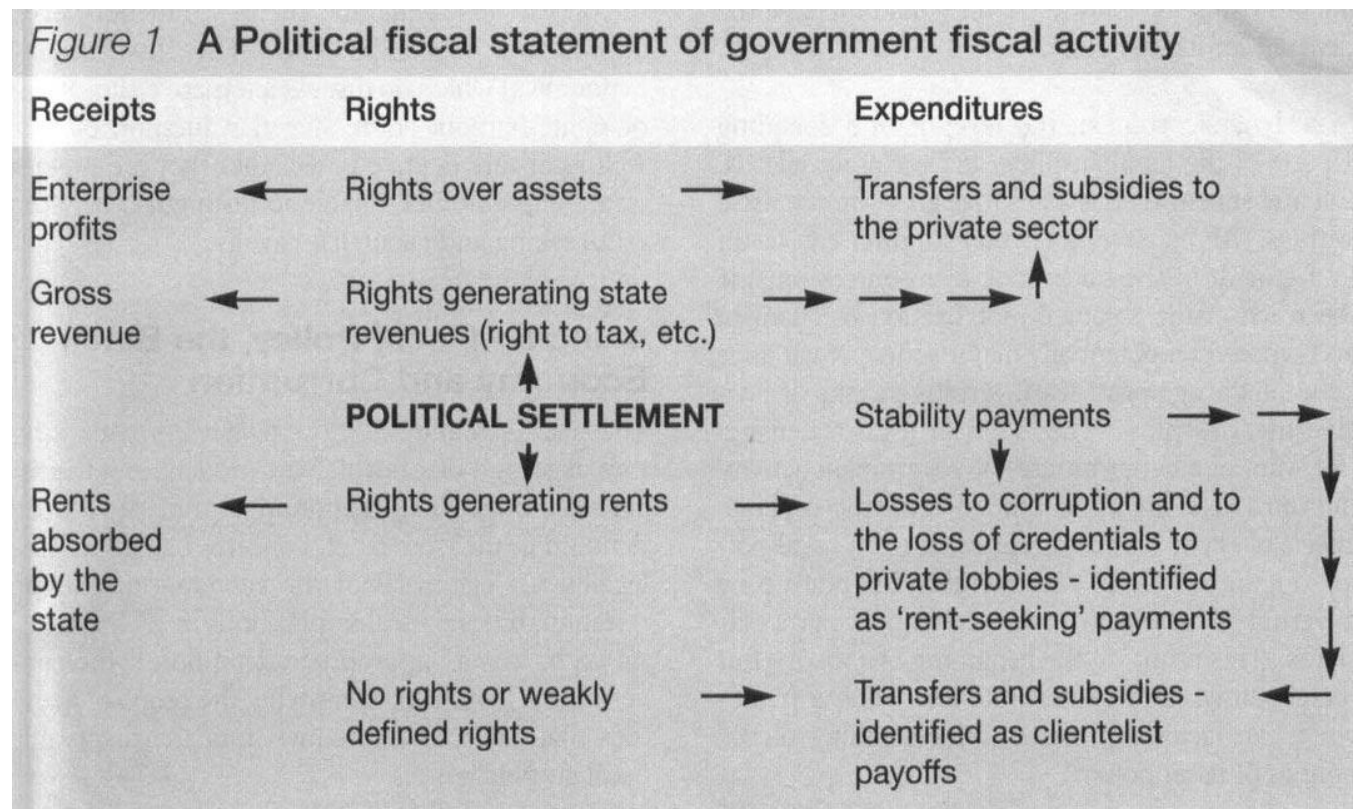

in themselves generated by the restriction of the activities of producing and consuming agents through the supply of credentials by the state. Corruption here only signals the distribution of rents between those employed in the public sector and those outside it; in principle it makes no difference if these rents were distributed differently. State failure in the NPE and liberal pluralist paradigms is consistent with rent-seeking. In fact rent-seeking is exposed as a major reason for reducing the scope and role of the state in economic activity (Lal 1988). Public 'corruption' signals economic inefficiency rather than political instability.

\subsection{Clientelism, corruption and fiscal policy}

To what extent does clientelism generate black economic activity? This depends on the sources of attrition from the disposable fiscal surplus that are caused by clientelist activity. The areas and magnitudes of clientelist activity require location in a particular context. If corruption is a significant source of a drain in the disposable fiscal surplus then rentseeking explanations would be valid. On the other hand, if other types of clientelist activity cause a lower disposable fiscal surplus then the rent-seeking diagnosis, and the implied correction - a shrinkage in the domain of state intervention - would be invalid. Corruption would then be a symptom of the wider emergence of clientelism.

What impact does black income generation have on the disposable fiscal surplus? Clearly, the most obvious impact is that of reducing the size of the fiscal surplus itself. The larger the size of the black economy, the lower, ceteris paribus, the tax base. Further, if there is a positive relationship between black income and public expenditure, then this reduces the disposable fiscal surplus - indeed this would be the focus of 'rent-seeking' type analyses. Hence, if we are able to investigate the mode of black income generation and its disposition, we can obtain clues as to whether clientelistic activity is an important element in the reduction in the disposable fiscal surplus.

\subsection{The black economy in India}

The black economy has been a source of concern in India. This concern arises from the persistently low and declining share of direct taxation (Table 1) and its relatively low elasticity and buoyancy.

A series of committees and independent scholars (GOI 1978, 1985; Chugh and Uppal 1986) have reported corruption as a major cause of the black economy. The size and volume of public corruption 


\section{Table 1 Direct and indirect tax/GDP ratios by level of government}

\section{All India Taxes}

$\begin{array}{cccc}\text { Year } & \text { All } & \text { Direct } & \text { Indirect } \\ 1950-51 & 6.56 & 2.42 & 4.14 \\ 1955-56 & 7.48 & 2.52 & 4.96 \\ 1960-61 & 8.99 & 2.68 & 6.31 \\ 1965-66 & 12.12 & 3.04 & 9.08 \\ 1970-71 & 11.80 & 2.50 & 9.30 \\ 1975-76 & 15.04 & 3.35 & 11.69 \\ 1980-81 & 15.57 & 2.56 & 13.01 \\ 1985-86 & 17.76 & 2.57 & 15.19\end{array}$

was cited as an important reason for the vicious nature of the black income-tax evasion nexus. At the same time, the size and volume of the black economy in India is viewed as providing major empirical support for rent-seeking arguments. It is argued that extensive state intervention and controls gave rise to a large underground economy and to increasing exaction of rents by those managing these controls. Jointly these activities contributed in a major way to the 'softening' of the budget constraint and to state failure (Lal 1988).

The clearest ideas on the source, magnitude and impact of black transactions on government fiscal policy are contained in a government report (henceforth GOI 1985) on 'black' activities in India. 'Black money' can be defined in several ways, but if the focus of interest is on its impact on the fiscal surplus, then we can use the official definition from the report: 'The aggregate of incomes which are taxable but are not reported to the tax authorities' (GOI 1985: 7). This term includes tax-evaded legal income plus all illegal incomes and transfer payments.

In aggregate terms, of the several estimates of the magnitude of black income generation in India the most recent is the GOI 1985 report which came up with two estimates of black income generated in India, presented in Table 2.

While these estimates indicate the magnitude of the problem, a detailed analysis indicates that the major problem with black money generation is not public corruption and rent-seeking, at least in a proximate way.
To substantiate, we look at black money generation in the public sector. Black income generating opportunities in the public sector can be distinguished by public controls over private sector activity and by direct public sector participation in economic activity. In both these categories, corruption reduces the disposable fiscal surplus when it constitutes an illegal transfer from the public account to private individuals, unlike bribes between individuals which do not alter the total of gross personal income in the economy or the distribution of public and private national product. Hence, and in view of our distinction between clientelism and rent-seeking, it is the latter that must be at the focus of our attention.

The GOI 1985 report did not attempt any systematic calculation of the volumes of such transfers. Instead, it viewed piecemeal evidence from previous literature which indicated that leakages were a pervasive phenomenon. From the evidence, it is possible to make the following simple macroeconomic calculation to generate a conservative pointestimate of 'leakages' from the public sector for two years, $1975-76$ and 1980-81.

Government expenditure $=$ Government purchases of commodities and services + Payments of wages and salaries + Gross public capital formation.

Deducting the third item leaves us with the corruption base. Assuming a 10 per cent rate of leakage from the remainder gives us a 'leakage' ratio amounting to between 10 and 15 per cent of total government final expenditure in 1992-93 and no more than between 5 and 6 per cent of total black 


\begin{tabular}{|c|c|c|}
\hline Item & $1975-76$ & $1980-81$ \\
\hline Tax evaded income & 37410 & 98130 \\
\hline Illegal activities & $33180-49780$ & 57130 to 85700 \\
\hline $\begin{array}{l}\text { Under-declared immovable } \\
\text { property values }\end{array}$ & 22560 & 36640 \\
\hline Leakages from the public sector & 1540 (maximum) & 4190 (maximum) \\
\hline $\begin{array}{l}\text { Leakages from the private } \\
\text { corporate sector }\end{array}$ & 2530 (maximum) & 3250 (maximum) \\
\hline Under invoicing of exports & 1390 & 2350 \\
\hline Global black money estimate & 99580 to 118700 & 203620 to 236780 \\
\hline $\begin{array}{l}\text { As a percentage of GDP at factor } \\
\text { cost, current prices }\end{array}$ & 15 to 18 & 18 to 21 \\
\hline $\begin{array}{l}\text { Leakages total (and as \% of } \\
\text { black income) }\end{array}$ & $4070(4.09)$ & $7440(3.66)$ \\
\hline
\end{tabular}

income (GOI 1985 estimate) in both. 1975-76 and 1980-81.

The 10 per cent leakage rate was estimated on the following basis:

i GOI 1985 found from literature and investigations that a bribe of 9-15 per cent was the standard 'take' for construction activity;

ii GOI 1985 stresses that leakages from purchases of commodities and services need to be corrected for the fact that the central government supplies department and public enterprises often purchased goods and services from other public sector enterprises, definitionally not allowing for black money generation there;

iii foreign suppliers allow for a cushion of 7 per cent in the supply of goods and services to the public sector according to GOI 1985.

To this we can add the 'kickbacks' from private sector investment to public managers and bureaucrats. This amounts to Rs. 1690 million for 1975-
76 and Rs. 2170 million for 1980-81, using the same 10 per cent criterion, applied here to total private capital formation. The total volumes are again not significant or predominant in the global picture of black income generation provided by the GOI (1985) report (Table 2).

From this global calculation of the magnitude of black income in India, it can be inferred that 'leakages' from public and private sector activities amounted to no more than 4.09 per cent of total black income in 1975-76 and 3.6 per cent in 198081. Indeed the bulk of black income generation comes from weakness in state fiscal capacity reflected in either activities outside the ambit of the GDP accounting mechanism or activities that relate to property transactions (GOI 1985: 342-343).

More clues are provided by looking at the sources of black income generation and the forms in which black wealth is held. The speculation that black income is generated through clientelist activity is based on a study of its sectoral generation, part of GOI (1985). ${ }^{7}$ We have ranked the sectors which this study found significant in generating black

\footnotetext{
${ }^{7}$ This is based on a questionnaire to all Income Tax

Commissions.
} 


\section{Table 3 Aspects of the black economy in India: Selected data from the NIPFP qualitative study}

\section{Sectors/Activities}

Sectors Generating Black Income

Construction

Professionals

Film Industry

Trade

Large Scale Manufacturing

Hotels, Restaurants, etc.

Road Transport

Illegal Activities Generating Black Income

Smuggling

Selling of Licences \& Permits

Kickbacks, Bribes, etc.

Capital Gains on Real Estate Transactions

Methods of Black Income Generation

Suppression or Understatement of Gross Receipts

Exaggeration of Expenses

Under Valuation of Assets

'Benami' Business

Forms in Which Black Wealth is Held

Shown as Income Deriving from Agricultural Activity

Undervalues Real Estate

Held in Precious Metals or Jewellery

Undervalued Business Equipment, Stocks, etc.
Significance Rating (\%)

77.6

77.9

91.1

69.2

89.5

43.6

50.0

90.8

48.4

57.4

92.4

96.1

83.6

83.6

51.5

93.7

96.0

74.6

65.1 activities in Table 3. Except large-scale manufacturing, the other significant areas of black income generation were found to be primarily areas of petty bourgeois activity - the domain of the 'trader, contractor and estate agent'. This points to the build-up of a significant wealth-owning and wealthgenerating constituency outside the dominant coalition as defined by Bardhan (1984). ${ }^{8}$

The mode of black income generation and the forms of holding black wealth would also tell us more about the locus of black activity. If corruption

${ }^{8}$ The rise of this group and its role in accumulation and disposition of black income is detailed in Roy (1994) is important then one would expect a significant chunk of black income to be held in benami businesses. In the GOI (1985) survey, the most significant mode of generating black income was found to be either complete or major understatement of gross receipts, a purely private corporate sector activity. Benami financial investment was held to be the least significant of the four modes of black income generation (Table 3). Finally, the form in which wealth generated from black activity was held was found, typically, to be not cash - (the form in which corruption is often paid off) - but

\footnotetext{
${ }^{9}$ Benami businesses are businesses run by agents of those who invest in the business, enabling the actual owners to conceal their ownership. This is the obvious way in which corrupt proceeds can be invested.
} 
undervalued real estate and stock in trade and previous metals, both forms in which black wealth is typically held by the 'nouveaux riches' tradercontractors.

\section{Conclusion}

The relationship between corruption, rent-seeking and state failure in India is more ambivalent than the present consensus suggests. Corruption can be placed in context by looking at its impact on the disposable fiscal surplus, particularly its role as a subset of activities generating black income. Corruption does not have any major direct impact on the disposable fiscal surplus in absolute or relative terms. Other activities are more important and the locus of these activities must be investigated separately from rent-seeking explanations of state failure. If the existence of corruption, within clientelist activity, reflects weakly defined rights, then corruption can be seen as a symptom of a malady whose remedy would not lie in passive acceptance of the proposition that the state must narrow its activity boundaries, as rent-seeking explanations all imply. Certainly, the role of corruption is shaping the political economy of Indian development policy needs to be more closely looked at from this, less consensual, perspective. ${ }^{10}$

\footnotetext{
${ }^{10}$ Recent investigations in India reveal that little attention has been paid since 1985 to the phenomenon of black income generation and the attendant consequences of corruption. A recently released report on political corruption (Government of India 1995) mentioned, but did not explore the problem highlighted. Access to the documents accompanying the latter report, presently confidential, may provide fresh information when released.
}

\section{REFERENCES}

Bardhan, P., 1984, The Political Economy of Development in India, Oxford: Basil Blackwell

Buchanan, J., 1980, 'Rent-seeking and profit seeking' in J. Buchanan, G. Tollison and G. Tullock (eds), Towards a Theory of the Rent-Seeking Society, College Station: Texas A\&M University Press

Chang, H.J., 1994, The Political Economy of Industrial Policy, London: Macmillan

Chugh, R.L. and Uppal, J.S., 1986, Black Economy in India, New Delhi: Tata McGraw Hill

Government of India, Ministry of Finance, 1978, Report of the Committee on Controls and Subsidies, New Delhi

1985, Aspects of the Black Economy in India, New Delhi

Government of India, Ministry of Home Affairs, 1995, Vohra Committee Report, New Delhi

Khan, Mushtaq, 1989, 'Clientelism, corruption and capitalist development, PhD thesis, University of Cambridge

1996, 'A typology of corrupt transactions in developing countries', IDS Bulletin, Vol 27 No 2, April
Krueger, A., 1974, 'The political economy of the' rent-seeking society', American Economic Review Vol 64

Lal, D., 1988, Hindu Equilibrium Cultural Stability and Economic Stagnation, India, c 1500 BC-1980 AD Vol 1, Oxford: Clarendon Press

Monga, G.S. and Sanctis, V.J., 1984, The Unsanctioned Economy in India, New Delhi: Himalaya Publishing

Rangnekar, D.K., 1974, 'Inflation, taxation and the black economy', Economic Times, Annual

Roy, R., 1994, 'The political economy of fiscal policy', PhD thesis, University of Cambridge

1995, 'The political economy of Indian fiscal policy: towards an alternative hypothesis of state failure?' Paper presented at the Cambridge Seminars on the Political Economy of Development, Cambridge, 7 February

Rudolph, L. and Rudolph, S., 1987, In Pursuit of Lakshmi: The Political Economy of the Indian State, Chicago: Chicago University Press 